\title{
B2B Brand Management and Private Labels Products
}

\author{
Flavio Gnecchi (Full Professor of Marketing)
}

University of Milan-Bicocca, Italy

Doi:10.19044/esj.2018.v14n28p115 URL:http://dx.doi.org/10.19044/esj.2018.v14n28p115

\begin{abstract}
Brand management always requires the definition of a strategy, in order to maintain and strengthen relationships with customers. Brand management makes it possible for companies to pursue a variety of goals, which is the aim of every company. This is irrespective of the fact that every organization can scale their intensity and priorities on the basis of their specific strategic guidelines, influenced by endogenous and exogenous variables to the company. Also in $\mathrm{B} 2 \mathrm{~B}$, it is crucial to properly assess the opportunities, and the related commitments, linked to brand management. A particular businessto-business context occurs due to the progressively growing phenomenon of private labels. After their success in supermarkets, private labels have also gained a foothold in the wholesale trade. Therefore, for some manufacturing firms, a different channel is feasible and is represented by commercial companies that wish to submit their own brand products to end customers (supermarket chains) and professional operators (wholesale warehouses).
\end{abstract}

Keywords: B2B, brand, management, private labels

\section{Introduction}

Is it possible to state that the commercial offer of goods and services for the final demand (B2C) is more concentrated, or simpler, or better known than the offer addressed to derived demand (B2B)?

There is no certain answer to this question. However, what is certain is that to most people (consumers), the subject-matter of many negotiations aimed at meeting derived demand is unknown.

The following analysis is based on a case study methodology and the observation of the best Italian practices, especially in the food and in the grocery sectors.

Particularly, some tender specifications have been examined, as well the communications delivered to the market by the companies involved in this matter. Furthermore, some companies have accepted a confidential meeting to explain their strategies. 


\section{Business-to-Business Brands}

Based on certain features that distinguish transactions between enterprises, the business-to-business brand, despite confirming many hallmarks of consumer markets, has some specific traits including:

- motivations for purchasing,

- the elements of the commercial offer preferred by customers, and

- the long-term development of the relationship between sellers and buyers.

Therefore, brand management requires the definition of a strategy. This is in addition to appropriate policies and coherent actions to build, maintain, and strengthen relationships with customers. Furthermore, these companies will then prepare an offer addressed to their customers (other companies that will use the items they buy to produce goods or services, or consumers that will act just to satisfy their private needs).

The critical nature of these relationships was acknowledged both by suppliers and customers. For example, for complex goods or services characterized by marked technical relevance, suppliers frequently involve their customers in the development process of their products.

Hence, it appears that in business management of companies involved in $\mathrm{B} 2 \mathrm{~B}$, it is crucial to properly assess the opportunities, and the related commitments, linked to brand management.

A consistent and effective brand management makes it possible to pursue a variety of goals, which every company aims for, although every organization can scale their intensity and priorities. On the basis of their specific strategic guidelines, organizations are influenced by endogenous and exogenous variables in regards to the company (the latter, in particular, is dependent on the specific context in which the enterprise works).

The most significant aims related to the brand are associated with:

- the image (brand image, of course, but also corporate image);

- the profitability (increase in margins);

- the differentiation of the offer;

- the customer loyalty and retention;

- the development of new skills and new technologies.

However, these goals underline a higher target: the achievement of a specific brand identity (but also a business identity), attainable by adopting a clear strategy, and the related development of brand policies.

For any company without a recognizable identity, or even without an appropriate power and a relevant perception, business relationships run the risk of not starting or of losing power over time. Also, the opportunities of customer involvement in the development of its products could decrease significantly.

The awareness of the strength that a brand can carry typified the businessto-consumer world. In recent decades, this awareness has found, and is still 
finding, a strong foothold in business-to-business. However, this is because companies have realized that the differences between these two macro areas do not mean that in $\mathrm{B} 2 \mathrm{~B}$, the brand is not a significant asset as well. This also is similar to what happens when a direct relationship is established between a company and its end customer/consumer.

On the contrary, for the business-to-business brand, the relational connotation has been emphasized. Thus, this underlies the very definition of brand. The link between supply and demand, its intensity, its customization, and its mutual assumptions helps to determine the typical commitment to consider the brand among prominent corporate assets. Additionally, it helps to pursue the enhancement of brand equity in the management of intangible assets.

The fact that some products/services could be offered both to final and intermediate customers also needs to be taken into consideration.

So which context does the brand need to evaluate? Should some relationships be given priority to the detriment of others? Should the correlated offer be modulated? Adequate brand management must answer these and other questions.

\section{The Development of Relationships with the Business-to-Business Market}

The brand represents an immaterial dimension that does not have an exclusive impact on the business-to-consumer context. Nevertheless, stating this is anachronistic and -at least- rash.

Kotler and Pfoertsch (2006) argued that "in business-to-business (B2B), things are different - branding is not meant to be relevant. Many managers are convinced that it is a phenomenon confined only to consumers' products and markets. Their justification often relies on the fact that they are in a commodity business or specialty market and that customers naturally know a great deal about their products as well as their competitors' products. To them, brand loyalty is a non-rational behavior that applies to breakfast cereals and favorite jeans - it doesn't apply in the more "rational" world of business-tobusiness products. Products such as electric motors, crystal components, industrial lubricants or high-tech components are chosen through an objective decision-making process that only accounts for the so-called hard-facts like features/functionality, benefits, price, service, quality, etc.. Soft-facts like the reputation of the business, whether it is well known, is not of interest. Is it true? Does anybody really believe that people can turn themselves into unemotional and utterly rational machines when at work? We don't think so".

Considering what was observed in the previous paragraph, concerning the relational values of the brand, even companies that are exclusively engaged in business-to-business exchanges cannot be free from brand management issues. 
Yet Aaker (1991) observed, as early as in 1991, that the brands hold a power not limited to business-to-consumer markets, or consumer goods. Indeed, the brand under certain conditions can be even more important in a business-to-business context, where the search for an appropriate business partner for supply is even more targeted and it expands over time.

Not infrequently in company valuation ranges (or in the scale of priorities designed in order to study a strategic decision), the product/service, even in business-to-business, is secondary to the brand. Purchase transactions, even of extremely high value, are concluded because of the value of the brand (or brands) transferred. Hence, this is regardless of the material component, i.e. the underlying product.

It was observed that the product belongs to the "world of things", while the brand belongs to the "world of ideas".

This finding cannot be considered as correct only for consumer goods (or - generally - those that contribute to stimulating an emotion that is unlikely to alter the reasoning that pervades exchanges between enterprises). However, its value can also be extended to business-to-business.

Similar to final markets, even in intermediate markets, the brand assumes precise functions both for the customer and the seller. On the other hand, for the customer, the following functions are performed (Lambin, 2004):

- guidance;

- practicality;

- warranty;

- customization.

For the seller (manufacturer/distributor), the following functions are performed:

- positioning;

- communications;

- protection;

- capitalization;

- loyalty.

Undoubtedly, some circumstances highlight the obvious differences between business-to-consumer and business-to-business management.

For example, searching for customers is a function of the business where the supplier company works. This fact is certainly not lacking in the businessto-consumer. Nevertheless, in business-to-business, customers are often reduced to very few units and, therefore, the search for buyers/customers may be over after limited contacts. In this case, the brand is important not because it absolves the mentioned function, but for the inescapable relational values.

Experience, which manifests itself through the use of a product or a service and which is an essential factor for the development of trade relations between 
two enterprises, may not occur at all if the seller does not make his/her offer known to the customer.

Appropriate business communication which is aimed at stimulating interest for a specific offer is essential. Thus, this is without ignoring the fact that the intention is to create a long-term relationship.

It was previously stated that the value transferred to the customer, who knowingly understands it, was correlated with the "competition differential" that an enterprise must acquire and maintain in a bid to secure a competitive advantage. Among the sources of this advantage is the brand, in terms of name, sign, symbol, logo, and relationship with a specific target market.

Business-to-business companies have started taking advantage of opportunities to reconsider business communication, and, in this circumstance, to review the recipients of related actions. Kapferer (2004) notes that "the traditional problem faced by professional brands is their desire also to address a less professional audience. Modern management techniques advocate talking to the customer's customer".

These companies feel the need to make themselves known to a wider audience than the professional users of their products/services. Their goal is to pursue a "broader" image (reaching the minds of consumers of the goods to which they contributed with their own supplies), and not just building the "specific" image that concerns intermediate demand.

More thought needs to be given to the specificity of business-to-business relationships. This is because although it is true that corporate communication in its operating implementation methods does not have substantial differences with the business-to-consumer world, it is equally true that there are assumptions and contents to adapt to different contexts.

As previously noted, the particular needs of a professional client have emerged and, therefore, the importance of specific brand attributes and associations have also emerged.

First of all, it was observed that the business-to-business relationship is rarely short; its assumptions require a long period during which the relationship defines its characteristics and is enriched and strengthened.

Buyers are sensitive to certain elements, which may vary depending on the particular sector in which they operate. In fact, a food company requires special guarantees on the quality of the products purchased, the timeliness of deliveries, the suitability of the packaging, etc.. In manufacturing sectors, for small parts (drill bits, grinding wheels, etc.) or consumable production material (lubricants, hardware, etc.), the consumer looks for variety in catalogues, compliance, quality, technical information, timely delivery, etc. Thus, it is used for the purchase of machinery or equipment that the customer requires in terms of reliability, quality, precision, technical assistance, technical-designing advice, etc. 
Certainly, quality is a common element, in that the reuse of the purchase (and the prospect of having to reorder consistently in the future) determines a particular focus on this aspect. Subsequently, quality also contributes primarily to deliver value to the buyer, who knowingly understands it.

A business-to-business venture, understanding the potential of a relationship built through the brand, must transfer all these elements to the brand (which the company has built and launched). This is because they contribute to brand identity and brand relevance, and also helps to determine the brand perception and the brand equity.

\section{Private Labels and New Relationships}

A particular business-to-business context is due to the progressively growing phenomenon of private brands. Their progressive success is due to many reasons. Among them, the increasing quality of private labels products is the effect of the constant attention in regards to the relationship between retailers and their suppliers.

In this perspective, the cooperation between the retailer (demand) and the manufacturer (offer) must be investigated. Hence, their relationship is based on the strength and the relevance of the manufacturer's brand.

Private label sourcing pressures are driven by cost, quality, and speed in the market (Deloitte, 2015). In addition, they are also affected by the reputation, the image, and the reliability of the supplier and its corporate brand.

After their success in supermarkets, private labels have also gained a foothold in the wholesale trade. For example, one of the major players in the cash and carry sector, Metro, has a significant number of private brands. This is both in the food non-food offer, whose proposals are accepted by its professional customers.

What elements has Metro used to expand its offer gradually? It is definitely cost-effectiveness, as well as loyalty (which probably represent a corollary of the first cited reason). It also constitutes the strength that it has conveyed to its private labels, whose nature is not always communicated explicitly to buyers. Today, Metro manages a system revolving around a private label system, where it is easy to detect the presence of diversified and structured multi-brand portfolios.

The Italian branch of Metro, from its website, clearly expresses the multinational's attributes of its own brands (today the third retailer/wholesaler group in the world). For example, for the specific segment of grocers, and small retail traders which is an expression of traditional neighborhoods, Metro Italy makes the attributes of its private label explicit, like the mission, the identity, and the essence (Gnecchi, 2009).

However, for some manufacturing firms, a different channel is feasible, which is represented by commercial companies who wish to submit their own 
brand products to end customers (supermarket chains) and professional operators (wholesale warehouses).

The relationships between producers and commercial intermediaries (retailers) can expand on three levels:

- the supply of industrial brand products made by a company that, in addition to developing the policies and activities of marketing, is also interested in consumer marketing and is the protagonist of communication actions towards the people who purchase or consume such products (as previously explained, this case is not part of this discussion);

- the supply of unbranded products, typical of some categories that retailing offers to its customers, such as "fresh" products (i.e. products in the agro-food chain, fruit and vegetables, meat and fish). These are products for which consumers are provided with the knowledge of its origin (obligatory indication of geographical origin). However, the producer's identity remains unknown. This refers to the supply of private label products, made on commission from the commercial intermediary (usually a chain of supermarkets) by "copackers" (contract packers), or by manufacturing companies which on the client's request set up a specific production for a single client. This is after the evaluation of the consistency with their strategies.

Third level deserves further study. Copackers include companies whose visibility is high, owners of known and popular brands, which agree to the request of the distributor. On the other hand, it refers to companies unknown to the general public or even known only to insiders since they only produce on behalf of others.

It should be noted that smaller companies, and maybe without a brand that directly ties them to the final consumer, normally align themselves to the trade intermediary's request. This solves their problem to exploit their productive capacity and to find a channel for the commercialization of their products. Their brand (corporate) in this case represents an asset for building the relationship with the customer. The acceptance gained with the proposals placed on the store shelves results in a mutual advantage: for the distributor that benefits from sales of private label products, and also for the copacker, which in addition to economic returns, can see the strength of its corporate brand increased.

On the other hand, for companies known for their national brand (or industrial brand), granting the request of the major chains involves a reflection that, in addition to looking at previous assessments not dissimilar from this case (the saturation production capacity, business costs, simplification of commercial management, etc.), requires a reinterpretation of the corporate strategy. Being bound to a strong partner could mean - pro tempore - reliable future cash flows, and also a concentration of risk. This is in addition to an impact, not necessarily negative, on the corporate brand. 
In light of the growing purchasing power of major chains, a refusal by the producer must be based on a consistent strength of the brand (or brands). For example, a chain finding, itself, which denied the willingness to produce a certain product for it, and later decides to exclude (simply for retaliation) a company from the dominant brand of its category (thus a leading brand, may be marked by a widely known and unequivocal symbol, i.e. a brand icon), would be exposed to the risk of abandonment by its customers.

Imagine entering a supermarket today and not finding the most popular soft drink or best-known hazelnut/chocolate spread, or the best selling noodles, this is, to say the least, pure fantasy. These companies, in fact, can then deny their cooperation because they run basically zero risks of retaliation.

The problem arises for other companies, which were indeed the very clear majority.

For the producer, there are the two following situations:

- to already be a supplier of the distributor, and as such involved in a relationship of a brand name qualified by a particular size, associations and strengths; this relationship develops on the corporate brand, but it also depends on the considerations of industrial brands managed by the producer;

- not to be the retailer's supplier, and then forced to build a brand (centered on its corporate brand).

Two opposite behaviors can be found in response to the invitation to become a copacker:

- contrast/refusal; this results in the rejection of the application submitted by the intermediary, and may cause repercussions on the relationship, which possibly already exist, between the two parties (being shunned, blockades etc.);

- adjustment/acceptance; that can be attributed both to a precise and convinced commercial decision or to an acceptance which is basically forced, both due to pressure put on the company, and internal management that requires a recovery of revenues/profitability.

From what has been observed, the importance of the brand rises, especially in regards to identification by the distributor, and in subsequent negotiations, which - if concluded - are epitomized in a contractual agreement that governs all details of the supply relationship.

For example, the producer's identity is not always indicated on the labels of the items. This is because laws only require indication of the place of production. In this case, the omission of the producer's details, obviously included in the agreement between the two subjects, can be traced back to a specific request from both the manufacturer and the customer.

Nevertheless, this contractual provision is largely determined, in both parties' assessments, by the features of copacker's corporate brand. 
For the distributor, own brand management requires a series of evaluations, whose consequences result in policies capable of causing real opportunities which are able to influence company performance. Consequently, a wide range of factors (culture, corporate as well as the specific countries, the environment, external and internal, internationalization, globalization, etc.) have been variously collected and organized.

For the same distributor, there are opportunities from the application of generic brand strategies, combining them into a system that can be analyzed according to the following three dimensions.

In developing the brand, one of the decisions to be made is related to the options available to the following dimensions:

- wideness of the brand,

- depth of the brand,

- length of the brand.

Here, wideness means the number of goods or services offered to the market with a single brand. Depth means the "geographic" spread of the brands. Length refers to the positioning of the brands themselves.

Therefore, their analysis determines a range of possibilities in defining the brand strategy (Kotler \& Pfoertsch, 2006). The wideness is based on three options:

- Individual Brand are brands that exclusively qualify the offer of one product (or service), without explicit reference to the organization of the brand owner. This option makes it possible to direct the attention of recipients of the communication to a single focus, emphasizing the uniqueness of the proposal and its associated distinction, even if this takes a greater commitment of resources;

- Family Brand - unlike the previous option - is based on the sharing of a brand, between two or more products/services that have similarities/analogies/relationships (as in the case of a line or range of products). Family brand requires precisely familiarity and consistency between the products/services offered, meaning similar levels of quality, similar or comparable regions and marketing strategies (in terms of distribution, pricing, positioning, communication, etc.). Even in this case, there is no explicit reference to the organization owner of the brand;

- Corporate Brands (or otherwise Master Brands) is used when the brand of the company also acts as a commercial brand for its proposals. It is the expression of a specific corporate culture, which intends to assert and indeed promote - the positive associations that may arise in regards to the history, traditions, image, reputation, etc., of the company. In the long term, this can lead to beneficial effects, since it helps to strengthen the company's presence in the market. In business-to-business, it is a 
choice often used to create long-lasting relationships, especially in periods of economic difficulty and shrinking of product life cycles.

In brand management, from the intermediary's point of view, to pursue a policy focused on private label involves assessments about the brand extension. Nevertheless, for the producer, becoming a copacker on behalf of a commercial operator (retail or wholesale) means to choose a way to ensure results from an increasing strength of brand.

From an operative point of view, the experience shows the different behavior of competitors operating in the large retailer sector. Thus, contenders in exclusive retail areas are characterized by the growing importance of the offers of private label products.

These behaviors are the results of strategic assessments of intermediaries, which can be influenced by the brand of the copacker.

In fact, there are companies who pursue the policy of brand-sign (store brand), and there are also companies who give priority to the management of a single brand name (own brand) or several brands. This "contrast" proposes the dualism between mono-brand portfolio management and multi-brand.

However, this also put into consideration the fact that generic products can be developed (generic brand and also fighter brands) - or private label proposals - without any emphasis on the brand.

The underlying objective has been confirmed: the creation of exclusive brands, known and appreciated for the quality or the appropriateness of the underlying product, which is able to have an effect on the store loyalty acquired by the distributor.

However, situations also occur where there has been a mixed approach, which is based on a combination of policies. Each of the previously listed types is linked to a specific brand management policy.

In some situations, certain private brands, combined with an offer of special quality, have become own premium brands, bringing benefits not only to operators who launched them, but also to the companies who made the products.

So, private labels have an impact on the brand equity of the company. In defining its strategy focused on own brand, it cannot be anyway insensitive to the features that qualify the copacker's brand.

Considering the various parts of brand equity, the importance of brand loyalty is being stressed. Paying attention to the "switching" trend that characterizes a large part of consumers, particularly in FMCG, private label, thanks to the main feature which qualifies it in customer's eyes, or a high value for money, makes it possible to pursue a certain brand loyalty. This is due to positive effects on private brand heritage, as well for the brand name of commercial intermediaries. 


\section{Conclusion}

The private label phenomenon has further impacted the relationship between industry and distribution. It has been already marked by the gradual acquisition of power by the latter. This is due to the consequence of some factors, among which are the prerogatives conferred by the relationship direct- with end customers. Nevertheless, more market-oriented retail companies have become aware of the fact that, despite the advantage given by the relationship with end buyers, it is more remunerative to enhance the mutual value of the relationship with the producers that does not force them to suffer - pro-tempore - taxation (taxes, levies and procedures).

Nevertheless, the intermediary understands that the private brand enriches its own position, which rises to a "productive" role (although through third parties). Therefore, in practice, if on one hand it limits the development of the supply chain, it extends it as a result of orders placed to other manufacturing companies on the other hand.

Therefore, this makes the private label a powerful tool, not just as a commercial offer, but in the development of mighty business-to-business relationships.

\section{References:}

1. Aaker, D.A. (1991). Managing Brand Equity. New York: The Free Press

2. Aaker, D.A. (2005). Strategic Market Management. $10^{\text {th }}$ ed.. Hoboken: John Wiley \& Sons Inc.

3. Aaker, D.A. \& Joachimsthaler, E. (2000). Brand Leadership. New York: The Free Press.

4. Arrigo, E. (2009). Market-Driven Management, Global Competition and Corporate Responsibility, in Symphonya. Emerging Issues in Management (www.symphonya.unimib.it), n. 1. http://dx.doi.org/10.4468/2009.1.06arrigo

5. Arrigo, E. (2012). Alliances, Open Innovation and Outside-in Management, in Symphonya. Emerging Issues in Management (www.symphonya. unimib.it),

n. 2 . http://dx.doi.org/10.4468/2012.2.05arrigo

6. Batra, R. \& Sinha, I. (2000). Consumer-Level Factors Moderating The Success Of Private Label Brands, in Journal of Retailing, New York University, $\quad$ Volume $76 . \quad$ http://dx.doi.org/10.1016/S00224359(00)00027-0

7. Best, R. (2014). Market-Based Management, Harlow: Pearson Education Limited. 
8. Braak, A., Dekimpe, M.G., \& Geyskens, I. (2013). Retailer PrivateLabel Margins: The Role of Supplier and Quality-Tier Differentiation, in Journal of Marketing, Volume 77.

9. Brondoni, S.M. (2005). Managerial Economics and Global Competition, in Symphonya. Emerging Issues in Management (www.symphonya.unimib.it), $\mathrm{n}$. http://dx.doi.org/10.4468/2005.1.02brondoni

10. Brondoni, S.M. (2010). Ouverture de Marketing Channel and Global Markets, in Symphonya. Emerging Issues in Management (www.symphonya. unimib.it), $\mathrm{n}$. http://dx.doi.org/10.4468/2010.1.010uverture

11. Chimhundu, R. (2011). Private Label Marketing Performance: An Analysis of Historical trends Using Theories of cumulative Changes and Puncutuated Equilibrium, in Journal of Business and Management, Chapman University, Volume, n. 8.

12. Day, G. (1994). The Capabilities of Market-Driven Organizations, in Journal of Marketing, Vol. 58, No. 4.

13. Day, G. (1999). The Market Driven Organization, New York: The Free Press.

14. Deloitte (2015-2016). Private Labels Sourcing Survey.

15. Gnecchi, F. (2005). Brand Portfolio and Over Supply, in Symphonya. Emerging Issues in Management (www.symphonya.unimib.it), n. 1. http://dx.doi.org/10.4468/2005.1.05gnecchi

16. Gnecchi, F. (2009). Market-Driven Management, Market Space and Value Proposition, in Symphonya. Emerging Issues in Management (www.symphonya.unimib.it),

$\mathrm{n}$. http://dx.doi.org/10.4468/2009.2.04gnecchi

17. Gnecchi, F. (2009). La gestione di marca nelle relazioni business-tobusiness, Giappichelli, Torino.

18. Gnecchi, F. (2013). Retailing, Private Label and Global Competition, in Symphonya. Emerging Issues in Management (www.symphonya.unimib.it), $\mathrm{n}$. http://dx.doi.org/10.4468/2013.2.06gnecchi

19. Hutt, M.D. \& Speh, T.W. (2010). Business Marketing Management $b 2 b$, South Western Cengage Learning.

20. Kapferer, J.N. (2004). The New Strategic Brand Management, London: Kogan Page.

21. Keegan, W. \& Green, M.C. (2017). Global Marketing, $9^{\text {th }}$ ed., Harlow: Pearson Education.

22. Keller, K.L. (2013). Strategic Brand Management: Building, Measuring, and Managing Brand Equity. $4^{\text {th }}$ ed. Harlow: Pearson Education. 
23. Kotler, P. \& Pfoertsch, W. (2006). Business-to-business Brand Management, Berlin: Springer.

24. Lamb, C., Hair, J. \& Mc Daniel, C. (2013). $M K T G ~ 7,12^{\text {th }}$ ed., Mason: South-Western.

25. Lambin, J.J. (2004). Market-Driven Management, London: McMillan. 26. Lincoln, K. \& Thomassen, L. (2008). Private Label: Turning the Retail Brand Threat into Your Biggest Opportunity, Bodmin: MPG Books.

27. Nielsen (2014). The State of Private Label around the World.

28. Riboldazzi, S. (2015). Global Markets and Development Policies in Large-Scale Retailers, in Symphonya. Emerging Issues in Management (www. symphonya.unimib.it),

n. 3. http://dx.doi.org/10.4468/2015.5.02riboldazzi

29. Tassinari, V. (2005). Trade, Over-Supply and Global Markets. The Coop Italia Case, in Symphonya. Emerging Issues in Management (www. symphonya.unimib.it),

$\mathrm{n}$. 2. http://dx.doi.org/10.4468/2005.2.03tassinari 